\title{
Papers
}

\section{The Patients' Bill of Rights and post-retirement benefits: The effect on the DJIA}

Received: 20th December, 2001

\section{John H. Earl, Jr.}

is Associate Professor of Finance at the University of Richmond, where he has been for 21 years since graduating from Arizona State University in 1984 with a PhD in finance. His research interests include investments and financial statement analysis.

\section{David S. North}

is Assistant Professor of Finance at the University of Richmond. He has been there for two years since graduating from Michigan State University in 2000 with a PhD in finance. His research interests include corporate governance, mergers, discretionary accounting, and financial statement analysis.

\begin{abstract}
This study estimates the effect of a Patients' Bill of Rights on the valuation of the DJIA. It examines only the effect on the Dow firms of post-retirement healthcare benefits. Enactment of a Patients' Bill of Rights is estimated to increase the cost of providing healthcare to employees by 4 per cent. If this cost is not passed on to employees, the cost increases will reduce profits and EPS, which will impact stock prices. The impact of a 4 per cent increase in healthcare costs could translate into a reduction in the level of the DJIA of between 410.20 and 838.86 Dow points.
\end{abstract}

Keywords: healthcare; post-retirement; benefits; legislation

\section{Introduction}

If the Patients' Bill of Rights passes, insured people would 'gain' certain rights. These rights come at a cost to the healthcare system. The Congressional Budget Office (CBO) estimates that the Patients' Bill of Rights will increase healthcare insurance premiums by 4.0 per cent. Firms that provide healthcare insurance to their employees would either decide to absorb this increase, or pass it on to employees. The $\mathrm{CBO}$ estimates that 60 per cent of the cost increase will be mitigated by the firms through future earnings and passing on the increased costs to employees. The net increase in cost according to the $\mathrm{CBO}$ analysis would be 1.6 per cent.

Firms are not required to report their current non-retired employee healthcare costs separately in any quarterly or annual financial reports to the SEC. Firms are required though, to report post-retirement healthcare costs and total obligations per FAS-106. These post-retirement costs and obligations include both current retirees and current non-retired employees. FAS-106 does not estimate costs associated with current employees' healthcare costs, therefore the 
impact of the bill will be greater than what we show.

Our study estimates the effect on passage of the Patients' Bill of Rights on the valuation of the DJIA. The study examines only the effect on the Dow firms of post-retirement healthcare benefits, not pre-retirement healthcare benefits. Public information is only available for post-retirement healthcare benefits. We use various price-to-earnings ratios and a price-to-book value of equity ratio to estimate the effect of increased healthcare costs on the DJIA. The main findings are that a 1.6 per cent increase in healthcare costs could result in a reduction in the level of the DJIA of between 164.08 and 335.54 points and a corresponding loss of market capitalisation of between $\$ 19.7 \mathrm{bn}$ and $\$ 50.6$ bn. A 4.0 per cent increase in healthcare costs could result in a reduction in the level of the DJIA of between 410.20 and 838.86 points and a corresponding loss of market capitalisation of between $\$ 49.2 \mathrm{bn}$ and \$126.6bn.

While only a few UK and other non-US firms provide post-retirement benefits other than pensions, these benefits can amount to large liabilities despite the existence of national social security covering a large part of medical, health and welfare expenses. ${ }^{1}$

Additionally, this issue will be of particular relevance to UK and other non-US firms with operations in the US where the provision for such benefits is particularly significant. For example, in the UK the Urgent Issues Task Force (UITF) consensus pronouncement concerning accounting for post-retirement benefits other than pensions states: 'that post-retirement healthcare and other benefits accruing to former employees should be recognized in financial statements as liabilities according to the principles enunciated in
SSAP 24, Accounting for Pension Costs.' This treatment is essentially the same as stated in FAS-106. This issue will also be of relevance to firms looking to make acquisition in the USA. A recent example of a UK firm acquiring a US firm that had a sizeable post-retirement benefit liability is the British Petroleum acquisition of Amoco.

The rest of the paper is organised as follows. The next section briefly discusses both the Senate and House versions of the Patients' Bill of Rights. It also outlines the CBO's cost estimate of the Patients' Bill of Rights as well as the FAS-106 Statement. Following is a description of the methodology, the data, and the results of the study and, finally, the concluding remarks.

\section{Background and development}

\section{Bipartisan Patients' Bill of Rights Act (S. 1052)}

The Senate passed the Bipartisan Patients' Bill of Rights Act, (S. 1052) on 29th June, 2001. The bill would impose new requirements on the structure and operation of group health plans and issuers of health insurance and would provide members of health plans and insured individuals with new rights to obtain certain healthcare services. Those new rights include coverage of routine patient care costs in clinical trials funded by the National Institutes of Health or approved by the Food and Drug Administration; access to out-of-network providers, including hospital emergency departments; and access to paediatricians, obstetricians, gynaecologists, and other specialists.

The bill requires both internal and external review processes for members to appeal claims denied by health plans and insurers. It would amend the Employee Retirement Income Security Act to 
allow individuals to sue health plans and insurers for personal injury or wrongful death - in federal court for failure to comply with terms of the plan and in state court under state tort laws. The bill expands the availability of medical savings accounts (MSAs), increases the deduction for health insurance purchased by self-employed individuals, and provides tax credits for small businesses that purchase health insurance. These provisions would take effect beginning 1st October, 2002.

\section{Patients' rights compromise that passed the house}

A compromise bill between the GOP bill sponsor C. Norwood (R-GA) and the White House passed in the house by a 226-203 vote on 2nd August, 2001. The House Bill maintains most of the patient protections included in the Senate version: emergency room access, easier access to paediatricians and $\mathrm{OB} / \mathrm{GYN}$ care, access to experimental drugs, and an independent appeals boards to hear patient complaints against HMOs.

The major differences with the Senate bill lie in the areas of where suits can be brought, limits on damage awards, and expansions of Medical Savings Accounts (MSA). Non-economic damages and punitive damages are limited to $\$ 1.5 \mathrm{~m}$ each in the House bill and suits can only be brought against defendants that fail to comply with a recommendation of an external review board. The Senate bill limits damages in federal court to $\$ 1.5 \mathrm{~m}$ but has no limits on suits filed in state courts. Lawsuits against HMOs would be heard in state court applying federal law. Claims against employers would be heard in federal court applying ERISA provisions. Patients who lose an independent review can still file suit but must present clear and convincing evidence in court to support their claim (the defendant is granted a 'rebultable presumption'). States with patients' rights bills (ten states) can impose lower (not higher) caps than those contained in the House Bill. The bill now moves to a conference committee with the Senate. Differences between the House and Senate Bills are significant and a bill may not make it out of the conference committee. President Bush has stated that he will veto the Senate version, but would sign the House bill.

\section{Congressional Budget Office estimate of the Senate Bill (S. 1052)}

The CBO has issued a cost estimate of S. 1052, the Bipartisan Patients' Bill of Rights Act, as passed by the Senate on 29th June, 2001. The CBO estimates that S. 1052, if enacted, would ultimately increase the premiums for health plans sponsored by private employers (including self-employed individuals) and by state, local, or tribal governments by an average of 4.0 per cent, before accounting for the responses of plans, employers, and workers to the higher prices. The $\mathrm{CBO}$ estimates that the increase in premiums would be phased in over a period of five years after the effective date.

A breakdown of the estimated 4.0 per cent increase health insurance premiums for employer sponsored health insurance is shown in Table 1. It should be noted that 0.7 per cent out of the 4.0 per cent increase is due to 'Title IV -

Availability of Civil Remedies'. The Availability of Civil Remedies refers to the ability of individuals to sue health plans and insurers for personal injury or wrongful death in federal court for failure to comply with terms of the plan and in state court under state tort laws. This line item most likely would be reduced for the House Bill, due to the limits on suits filed in state courts. 
Table 1: Congressional Budget Office Cost Estimate on premiums for employer-sponsored health insurance

\begin{tabular}{|c|c|}
\hline Provisions & $\begin{array}{l}\text { Increase in } \\
\text { premiums } \\
\%\end{array}$ \\
\hline \multicolumn{2}{|l|}{ Subtitle A - Utilisation review, claims and appeals } \\
\hline Utilisation review activities & 0.2 \\
\hline Procedures for initial claims and prior authorisation & $0.0^{\mathrm{a}}$ \\
\hline Internal and external appeals & 0.9 \\
\hline \multicolumn{2}{|l|}{ Subtitle B - Access to care } \\
\hline Consumer choice & 0.1 \\
\hline Choice of healthcare professional & $0.0^{\mathrm{a}}$ \\
\hline Access to emergency care & 0.4 \\
\hline Access to specialty care & 0.3 \\
\hline Accres to obstetric and gynaecological care & 0.1 \\
\hline Access to paediatric care & $0.0^{\mathrm{a}}$ \\
\hline Continuity of care & 0.2 \\
\hline Access to needed drugs & $0.0^{\mathrm{a}}$ \\
\hline Clinical trials & 0.8 \\
\hline Treatment of breast cancer and second opinions & 0.2 \\
\hline Subtitle C - Access to information & 0.1 \\
\hline Subtitle D - Protecting the doctor-patient relationship & $0.0^{\mathrm{a}}$ \\
\hline \multicolumn{2}{|l|}{ Subtitle E - Definitions } \\
\hline Coverage of limited scope plans & $0.0^{\mathrm{a}}$ \\
\hline Title IV $\quad-$ Availability of civil remedies & 0.7 \\
\hline 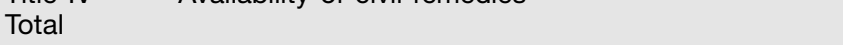 & 4.0 \\
\hline
\end{tabular}

aDenotes less than $0.05 \%$

This table is identical to Table 2 of the Congressional Budget Office Cost Estimate of H.R. 2563, the Bipartisan Patient Protection Act, as introduced on 19th July, 2001. This table is also identical to Table 2 of the Congressional Budget Office Cost Estimate of S. 1052, the Bipartisan Patients' Bill of Rights Act, as passed by the Senate on 29th June, 2001. The table is the estimated effect of H.R. 2563 \& S. 1052 on premiums for employer sponsored health insurance.

\section{FAS-106 Summary}

In December 1990 the Financial Accounting Standards Board (FASB) issued Summary of Statement No. 106 - Employers' Accounting for Post-retirement Benefits Other than Pensions (FAS-106). The Statement's effective date was for fiscal years beginning after 15th December, 1992. Post-retirement benefits consist of all forms of benefits other than retirement income provided by an employer to retired workers, their beneficiaries, and their dependents.

FAS-106 established accounting standards for employers' accounting for post-retirement benefits other than pensions. The Statement significantly changed the prevalent practice of accounting for post-retirement benefits on a pay-as-you-go (cash) basis by requiring accrual, during the years that the employee renders the necessary service, of the expected cost of providing those benefits to an employee and the employee's beneficiaries and covered dependants. In exchange for current services provided by the employee, the employer promises to provide, in addition to current wages and other benefits, certain health and other welfare benefits after retirement. Post-retirement benefits are part of an employee's compensation for services rendered. Since payment is deferred, the benefits are a type of deferred compensation. The employer's obligation for that compensation is incurred as employees render the services necessary to earn their post-retirement benefits.

FASB states that measurement of the obligation and accrual of the cost based on best estimates are superior to 
implying, that no obligation exists prior to the payment of benefits. Failure to recognise an obligation prior to its payment impairs the usefulness and integrity of the employer's financial statements.

An objective of FAS-106 is to enhance the ability of users of the employer's financial statements to understand the extent and effects of the employer's promise to provide post-retirement benefits to its employees by disclosing relevant information about the obligation and cost of the post-retirement benefit plan.

FAS-106 requires the employer to accrue the accumulated post-retirement benefit obligation. Once an employee has attained full eligibility, the amount of this obligation is the same as the employee's expected post-retirement benefit obligation. Until then, the accumulated amount is the portion of the expected amount attributed to employee service rendered to a particular date. The accumulated and the expected amounts represent the actuarial present value of the anticipated benefits. Measurement of these amounts is based on assumptions regarding the expected cost of providing the future benefits and any cost-sharing provisions under which the employee, the government, or others will absorb part of these costs. Additional assumptions are: the time value of money, expected long-term rate of return on plan assets, future compensation, participation rates for contributory plans, the probability of payment (such as turnover of employees, dependency status, and mortality), per capita claims cost, and assumptions about trends in healthcare costs. ${ }^{2}$ If the benefits or cost-sharing provisions are related to the employee's salary progression, the calculation of benefits and cost sharing reflects the anticipated impact of this progression.
Additionally, FAS-106 requires the recognition of net periodic post-retirement benefit cost. The amount of net periodic post-retirement benefit cost is derived from the net change in the amount of the accumulated post-retirement benefit obligation, after ignoring those components of the net change that do not pertain to the cost of benefits. The net periodic post-retirement benefit cost recognised for a period consists of: service cost, interest cost, actual return on plan assets, amortisation of unrecognised prior service cost, gain or loss, and amortisation of the unrecognised obligation or asset at the date of the initial application of FAS-106.

\section{FAS-106 Example: Minnesota, Mining \& Manufacturing}

An example of the standardised format required by FAS-106 is included in Table 2. Table 2 is a replication of the Notes to Consolidated Financial Statements as reported in Minnesota, Mining \& Manufacturing's 2000 Annual Report.

The note contains the assumptions utilised in the calculation of the accumulated post-retirement benefit obligation and the net periodic post-retirement benefit cost. There is a statement concerning the assumed healthcare inflation trend. Usually, the firm will include a per cent increase for the next year and a steady state per cent increase estimate, along with a stated steady state year.

Additionally a statement of the sensitivity to a change in the healthcare cost trend assumption is included. Firms report the effect on the current year's benefit expense and the effect on the benefit obligation, to a 1 per cent increase and 1 per cent decrease in the healthcare cost trend assumption. Minnesota, Mining \& Manufacturing, in Table 2, stated that a 1 per cent 
Table 2: Example of notes to Consolidated Financial Statements as reported in Annual Report

\begin{tabular}{|c|c|c|}
\hline $\begin{array}{l}\text { Minnesota Mining \& Manufacturing } \\
2000 \text { Annual Report }\end{array}$ & $\begin{array}{l}2000 \\
(\$ \mathrm{~m})\end{array}$ & $\begin{array}{l}1000 \\
(\$ \mathrm{~m})\end{array}$ \\
\hline \multicolumn{3}{|l|}{ Reconciliation of benefit obligation } \\
\hline Beginning balance & $\$ 1,016$ & $\$ 1,030$ \\
\hline Service Cost & 39 & 42 \\
\hline Interest Cost & 82 & 69 \\
\hline Participant contribution & 11 & 9 \\
\hline Foreign exchange rate changes & - & 1 \\
\hline Actuarial (gain) loss & 109 & (56) \\
\hline Benefit payments & $(91)$ & (79) \\
\hline Ending balance & $£ 1,166$ & $£ 1,016$ \\
\hline \multicolumn{3}{|l|}{ Reconciliation of plan assets at fair value } \\
\hline Beginning balance & $\$ 537$ & $\$ 523$ \\
\hline Actual return on plan assets & 4 & 19 \\
\hline Company contributions & 139 & 64 \\
\hline Participant contributions & 11 & 9 \\
\hline Foreign exchange rate changes & - & - \\
\hline Benefit payments & $(90)$ & (78) \\
\hline Ending balance & $\$ 601$ & $\$ 537$ \\
\hline \multicolumn{3}{|l|}{ Funded status of plans } \\
\hline Plan assets at fair value less benefit obligation & $\$(565)$ & $\$(480)$ \\
\hline Unrecognised transition (asset) obligation & - & - \\
\hline Unrecognised prior service cost & (26) & 12 \\
\hline Unrecognised (gain) loss & 160 & (37) \\
\hline Net amount recognised & $\$(431)$ & $\$(505)$ \\
\hline \multicolumn{3}{|c|}{ Amounts recognised in the Consolidated Balance Sheet consist of: } \\
\hline Prepaid assets & - & - \\
\hline Accrued liabilities & $(431)$ & (505) \\
\hline Intangible assets & - & - \\
\hline Accumulated other comprehensive income (pre-tax) & - & - \\
\hline Net amount recognised & $\$(431)$ & $\$(505)$ \\
\hline \multicolumn{3}{|l|}{ Components of net periodic benefit cost } \\
\hline Service cost & $\$ 39$ & $\$ 42$ \\
\hline Interest cost & 82 & 69 \\
\hline Expected return on assets & $(47)$ & (34) \\
\hline Amortisation of transition (asset) obligation & - & - \\
\hline Amortisation of prior service cost or benefit & $(11)$ & 11 \\
\hline Recognised net actuarial (gain) loss & 3 & - \\
\hline Net periodic benefit cost & $\$ 66$ & $\$ 66$ \\
\hline \multicolumn{3}{|l|}{ Weighted average assumptions } \\
\hline Discount rate & $7.50 \%$ & $7.50 \%$ \\
\hline Expected return on assets & $8.19 \%$ & $8.19 \%$ \\
\hline Compensation rate increases & $4.65 \%$ & $4.65 \%$ \\
\hline \multicolumn{3}{|c|}{$\begin{array}{l}\text { 'The company expects its healthcare cost trend for post-retirement benefits to slow from } 5.8 \% \text { in } 2001 \text { to } 5 \% \\
\text { in } 2004 \text {, after which the rate is expected to stabilise. A one percentage point change in the assumed health } \\
\text { care cost trend rates would have the effects shown in the following table:' }\end{array}$} \\
\hline Healthcare cost & $\begin{array}{l}\text { One percentage } \\
\text { point increase } \\
(\$ \mathrm{~m})\end{array}$ & $\begin{array}{l}\text { One percentage } \\
\text { point decrease } \\
(\$ \mathrm{~m})\end{array}$ \\
\hline Effect on current year's benefit expense & $\$ 16.0$ & $\$(13.0)$ \\
\hline Effect on benefit obligation & $\$ 119.0$ & $\$(103.0)$ \\
\hline
\end{tabular}

This table displays Minnesota Mining \& Manufacturing's note to consolidated financial statements concerning FASB 106, from the firm's fiscal year 2000 Annual Report

increase in their healthcare trend assumption will increase the current years benefit expense by $\$ 16.0 \mathrm{~m}$, increasing their benefit expense on their income statement from $\$ 66.0 \mathrm{~m}$ to $\$ 82.0 \mathrm{~m}$, a 24.2 per cent increase. The impact on their benefit obligation (balance sheet) would be $\$ 119.0 \mathrm{~m}$, 
Table 3: Net periodic benefit cost and benefit obligation

\begin{tabular}{|c|c|c|c|c|}
\hline & \multicolumn{2}{|c|}{ Fiscal year 2000} & \multicolumn{2}{|c|}{$\begin{array}{l}\text { Reported effect of } 1 \% \\
\text { increase in healthcare } \\
\text { cost trend rates on: }\end{array}$} \\
\hline & $\begin{array}{l}\text { Net periodic } \\
\text { benefit cost } \\
\text { (\$m) }\end{array}$ & $\begin{array}{l}\text { Benefit } \\
\text { obligation } \\
\text { (\$m) }\end{array}$ & $\begin{array}{l}\text { Net periodic } \\
\text { benefit cost } \\
(\$ \mathrm{~m})\end{array}$ & $\begin{array}{l}\text { Benefit } \\
\text { obligation } \\
\text { (\$m) }\end{array}$ \\
\hline Alcoa, Inc. & 155.0 & $2,924.0$ & 13.0 & 165.0 \\
\hline American Express Co. & 26.0 & 211.0 & $3.1^{\mathrm{a}}$ & $18.6^{\mathrm{a}}$ \\
\hline AT\&T Corp. & 147.0 & $4,886.0$ & 9.0 & 125.0 \\
\hline Boeing Co. & 553.0 & $6,268.0$ & 64.0 & 603.0 \\
\hline Caterpillar Inc. & 259.0 & $3,869.0$ & 40.0 & 280.0 \\
\hline Citigroup Inc. & 24.0 & $1,015.0$ & 4.0 & 38.0 \\
\hline Coca-Cola Co. & 40.0 & 407.0 & 8.0 & 55.0 \\
\hline E.I. DuPont de Nemours & 309.0 & $5,126.0$ & 44.0 & 443.0 \\
\hline Eastman Kodak Co. & 126.0 & $2,602.0$ & 6.0 & 83.0 \\
\hline Exxon Mobil Corp. & 169.0 & $2,942.0$ & $20.3^{a}$ & $259.2^{\mathrm{a}}$ \\
\hline General Electric Co. & 478.0 & $6,422.0$ & 0.0 & 0.0 \\
\hline General Motors Corp. & $2,172.0$ & $49,889.0$ & 450.0 & $5,200.0$ \\
\hline Hewlett-Packard Co. & $(25.0)$ & 350.0 & 10.0 & 64.0 \\
\hline Home Depot, Inc. & 0.0 & 0.0 & 0.0 & 0.0 \\
\hline Honeywell International & 98.0 & $1,952.0$ & 11.0 & 130.0 \\
\hline Intel Corporation & 0.0 & 0.0 & 0.0 & 0.0 \\
\hline IBM & 374.0 & $6,443.0$ & 8.0 & 52.0 \\
\hline International Paper Co. & 45.0 & 822.0 & 0.0 & 63.0 \\
\hline J.P. Morgan Chase \& Co. & 32.0 & 918.0 & 1.7 & 48.7 \\
\hline Johnson \& Johnson & 55.0 & 722.0 & 11.0 & 89.0 \\
\hline McDonald's Corp. & 0.0 & 0.0 & 0.0 & 0.0 \\
\hline Merck \& Co., Inc. & $(25.5)$ & 909.8 & 18.7 & 145.4 \\
\hline Microsoft Corp. & 0.0 & 0.0 & 0.0 & 0.0 \\
\hline Minnesota Mining \& Mfg. & 66.0 & $1,166.0$ & 16.0 & 119.0 \\
\hline Phillip Morris Cos. & 230.0 & $3,323.0$ & 30.0 & 312.4 \\
\hline Proctor \& Gamble Co. & $(336.0)$ & $1,270.0$ & 23.0 & 167.0 \\
\hline SBC Comm. Inc & $1,011.0$ & $17,802.0$ & 192.0 & $1,999.0$ \\
\hline United Technologies & 72.0 & $1,175.0$ & 7.6 & 70.5 \\
\hline Wal-Mart Stores Inc. & 0.0 & 0.0 & 0.0 & 0.0 \\
\hline Walt Disney Co. & $31.0^{\mathrm{b}}$ & 413.0 & 12.0 & 87.0 \\
\hline Sum & $7,085.5$ & $123,826.8$ & 979.0 & $10,338.9$ \\
\hline Average & 236.2 & $4,127.6$ & 32.6 & 344.6 \\
\hline
\end{tabular}

a Sensitivity to a $1 \%$ increase in healthcare cost trend rates on both net periodic benefit cost and benefit obligation not specified in annual report. Sensitivity is estimated based on average of reporting firms ratio of corresponding sensitivity to cost or obligation.

${ }^{b}$ Firm does not report net periodic benefit cost. This figure is service cost plus interest cost.

This table displays the net periodic benefit cost and benefit obligation amounts reported in fiscal year 2000 annual reports. It also includes the reported sensitivities of these reported numbers to a 1 per cent increase in healthcare cost trend rates.

increasing their benefit obligation from $\$ 1,166.0 \mathrm{~m}$ to $\$ 1,235.0 \mathrm{~m}$, a 10.7 per cent increase.

\section{Methodology}

\section{The sample and financial data}

The sample for this study is the 30 firms that comprise the Dow Jones Industrial Average; data were collected from the recent 2000 fiscal year annual reports.
Table 3 displays the net periodic benefit cost and benefit obligation for the firms. Five firms report no net periodic benefit cost or benefit obligation; Home Depot, Intel, McDonald's, Microsoft, and Wal-Mart Stores. These firms do not offer post-retirement healthcare benefits. Three firms have reported negative net periodic benefit costs. This is due to certain components in the calculation of the net periodic benefit cost. For 
Table 4: Stated assumptions of annual rate of increase in covered healthcare benefits

\begin{tabular}{|c|c|c|c|}
\hline & $\begin{array}{l}2001 \text { rate } \\
\text { (per cent) }\end{array}$ & $\begin{array}{l}\text { Steady } \\
\text { state rate } \\
\text { (per cent) }\end{array}$ & $\begin{array}{l}\text { Steady } \\
\text { state } \\
\text { year }\end{array}$ \\
\hline Alcoa, Inc. & 8.50 & 5.50 & 2005 \\
\hline American Express $\mathrm{Co}^{\mathrm{a}}$ & n.a. & n.a. & n.a. \\
\hline AT\&T Corp. & 7.60 & 4.50 & 2010 \\
\hline Boeing Co. & 9.50 & 5.50 & 2010 \\
\hline Caterpillar Inc. & 5.10 & 4.50 & 2005 \\
\hline Citigroup Inc. & $7.75^{\mathrm{b}}$ & 5.00 & 2008 \\
\hline Coca-Cola Co. & 7.00 & 5.25 & 2005 \\
\hline E.I. DuPont de Nemours & 7.50 & 5.00 & 2004 \\
\hline Eastman Kodak Co. & 8.00 & 5.00 & 2004 \\
\hline Exxon Mobil Corp. $^{a}$ & n.a. & n.a. & n.a. \\
\hline General Electric Co. & 10.00 & 5.00 & 2009 \\
\hline General Motors Corp. & 8.00 & 5.00 & 2007 \\
\hline Hewlett-Packard Co. & 7.80 & 5.50 & 2007 \\
\hline Home Depot, Inc. ${ }^{c}$ & n.a. & n.a. & n.a. \\
\hline Honeywell International & 6.00 & 6.00 & 2001 \\
\hline Intel Corporation ${ }^{c}$ & n.a. & n.a. & n.a. \\
\hline IBM & 6.00 & 6.00 & 2001 \\
\hline International Paper Co. & 6.50 & 5.00 & 2005 \\
\hline J.P. Morgan Chase \& Co. & 8.00 & 5.00 & 2006 \\
\hline Johnson \& Johnson & $8.00^{d}$ & 5.00 & 2008 \\
\hline McDonald's Corp. ${ }^{\mathrm{C}}$ & n.a. & n.a. & n.a. \\
\hline Merck \& Co., Inc. & 6.50 & 5.00 & 2004 \\
\hline Microsoft Corp. $^{c}$ & n.a. & n.a. & n.a. \\
\hline Minn. Mining \& Mfg. & 5.8 & 5.00 & 2004 \\
\hline Phillip Morris Cos. & 6.00 & 5.00 & 2003 \\
\hline Proctor \& Gamble Co. & 5.8 & 5.00 & 2006 \\
\hline SBC Comm. Inc. & $8.50^{\mathrm{e}}$ & 5.00 & 2006 \\
\hline United Technologies & 7.50 & 7.50 & 2001 \\
\hline Wal-Mart Stores, Inc. ${ }^{c}$ & n.a. & n.a. & n.a. \\
\hline Walt Disney Co. & 7.50 & 5.00 & 2009 \\
\hline Average & 7.34 & 5.23 & 2005.6 \\
\hline
\end{tabular}

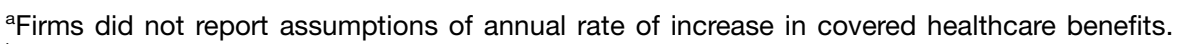

${ }^{b}$ Figure is an average of a range of initial annual rates of increases in covered healthcare benefits reported by firm, ranging from $7.00 \%$ to $8.50 \%$.

${ }^{c}$ Firm did not have any net periodic benefit cost or benefit obligation.

${ }^{\mathrm{d}}$ Figure is an average of a range of initial annual rates of increases in covered healthcare benefits reported by firm, ranging from $7.00 \%$ to $9.00 \%$.

${ }^{e}$ Figure is an average of a range of initial annual rates of increases in covered healthcare benefits reported by firm, ranging from $8.00 \%$ to $9.00 \%$.

In their annual report, firms report annual rates of increases in the per capita cost of covered healthcare benefits assumed in the calculation of net periodic benefits cost and benefit obligation. Firms usually report the initial rate for 2001 and a steady state rate. Firms state that the rate is assumed to decrease gradually to a stated, steady state year.

example, the expected return on plan assets and/or an actuarial gain could be greater than the service cost plus interest cost, creating a negative benefit cost.

Table 3 displays the reported effect of a 1 per cent increase in healthcare cost trend rate assumptions on the net periodic benefit cost and benefit obligation. In total, the firms' report that a 1 per cent increase in healthcare trend rate assumptions will increase net periodic benefit costs in 2000 by $\$ 979.0 \mathrm{~m}$, increasing their benefit expense from $\$ 7,085.5 \mathrm{~m}$ to $\$ 8064.5 \mathrm{~m}$, an increase of 13.8 per cent. The 1 per cent increase in their healthcare trend rate assumption will increase their benefit obligation by $\$ 10,338.9 \mathrm{~m}$, increasing their benefit obligation from

$\$ 123,826.8 \mathrm{~m}$ to $\$ 134,165.7 \mathrm{~m}$, an increase of 8.3 per cent. 
Table 5: Historical and projected increases in employer healthcare costs ${ }^{5,6,7}$

\begin{tabular}{llllllllllll}
\hline Year & 1991 & 1992 & 1993 & 1994 & 1995 & 1996 & 1997 & 1998 & 1999 & 2000 & 2001 \\
\hline$\%$ Increase & $12.0 \%$ & $10.0 \%$ & $8.0 \%$ & $4.6 \%$ & $1.9 \%$ & $6.0 \%$ & $2.2 \%$ & $2.7 \%$ & $7.0 \%$ & $12.0 \%$ & $13.0 \%$ \\
\hline
\end{tabular}

\section{Healthcare cost trends}

In Table 4 the average annual rate of increase in the per capita cost of healthcare benefits used to calculate net periodic benefits cost and benefit obligation by the Dow 30 stocks averaged 7.34 per cent. The steady state rate averaged 5.23 per cent taking effect in the year 2005 (2005.6) FASB 106 required implementation by 1993 . In 1993 the rate of healthcare inflation experienced by large firms was 8 per cent, down from 12 per cent in 1991. Based on this level and trend 7.34 per cent and 5.23 per cent represented reasonable projections. From 1994 to 1998 actual cost increases fell substantially below the actually assumed rates allowing aggressive firms to generate income from their healthcare plans.

FAS-106 required companies to estimate their retiree healthcare liabilities, which in 1993 were escalating at double digit rates. The estimated cost was expensed to the income statement as a one time extraordinary charge and identified in a balance sheet footnote as a liability. The magnitude of the charges encouraged many firms to reduce the medical benefits offered to current and future retirees. When medical inflation dropped sharply from 1994-1999 the estimated liability was overstated and firms adjusted their liability downward generating gains to their income statement and EPS. Sears Roebuck and Co. added $\$ 38 \mathrm{~m}$ to its bottom line in 1998 and $\$ 46 \mathrm{~m}$ in $1999 .{ }^{3}$ Proctor and Gamble's retiree medical program accounted for $\$ 336 \mathrm{~m}$ in pre tax income, greater than 6 per cent of the company's pre tax earnings. ${ }^{4}$
Procter and Gamble retiree medical plan has contributed positively to its bottom line every year since 1994 , totaling $\$ 909 \mathrm{~m}$ in pre tax income. The company, like many large firms, set up a trust fund to pay for projected retirement healthcare costs. The combination of a bullish stuck market and lower than projected healthcare inflation has generated the profits. As of 30th June, 2000 Procter and Gamble's trust assets were $\$ 1.3 \mathrm{bn}$. Unfortunately the trends in healthcare inflation and the stock market have reversed. Healthcare inflation is currently at 12 per cent and projected to remain at that level through 2003-2005. Stock market returns have been negative since the NASDAQ hit its peak in March of 2000. The factors that combined to generate plan profits from 1994-2000 will now lead to losses. The Patients' Bill of Rights will increase the rate of healthcare inflation and magnify the trend.

In 1999 healthcare costs increased by 7 per cent roughly equal to the rate assumed by the Dow 30 . The $12-13$ per cent rate increases experienced in 2000 and 2001 are significantly above the actuarially assumed rates in Table 4 . The 13 per cent increase expected in 2001 is the highest rate in the ten plus years of the Towers Perrin Health Care Cost Survey. The 2002 rate of increase is expected to be 12 per cent by survey participants: 11 per cent for PPOs, 12 per cent for HMOs, and 16 per cent for Medicare HMOs. For the 2003-05 period 45 per cent of respondents expected rate increases above the 2002 level, 45 per cent expected roughly the same level of increase, and 9 per cent 
thought rate increases would moderate. ${ }^{7}$ Clearly the successes of HMOs/PPOs in controlling healthcare costs in the 1993-1998 time period are over. A backlash against cost controls and barriers to access are partially responsible for the escalation on healthcare costs.

The increase in costs has been higher for retirees (especially those over 65) than for active workers. Healthcare providers are under pressure from shareholders demanding increased profitability, market demographics, and increases in prescription drug prices. Increased demand for prescription drugs combined with reduced government Medicare reimbursements have forced HMOs to recoup lost revenues elsewhere.

Employers are facing escalating costs to provide healthcare benefits to employees. The average cost of family coverage rose to $\$ 7,020$ in 2000 (up $\$ 585$ ). Employees pay on average 19 per cent of the cost of employee-only coverage and 22 per cent of family coverage. Retirees pay 38-40 per cent of retiree only coverage. Employers are reacting to the cost increases by adjusting plan design and cost sharing features. Last year 30 per cent of employers passed on the proportional increase in costs to employees, while 40 per cent passed on a greater than proportional share to their employees.

According to the $\mathrm{CBO}$ cost assessment, S1052/HR2563 will increase employee healthcare costs by an additional 4 per cent, adding 'fuel to the fire' of cost containment. The CBO states that 60 per cent of the increase will be offset by changes in profits and by purchasers switching to less expensive plans, cutting back on fringe benefits, or dropping coverage. Most of the remaining 40 per cent of the increase, or about 1.6 per cent of health insurance costs, would be passed through to workers, reducing both their taxable compensation and other fringe benefits. For employees of private firms, CBO assumes that all of that increase would ultimately be passed through to workers.

\section{Calculating the effect of the Patients' Bill of Rights on the DJIA}

The focal point of this study is to examine the effects of the Patients' Bill of Rights on the 30 Dow firms. Specifically, this paper will examine the income statement and balance sheet effects the bills implementation will have on the firm and the corresponding valuation implications.

Table 6 is a summary of the financial data for the 30 Dow firms as of $08 / 02 / 01$. Included in the table are share price, shares outstanding, and total market capitalisation. Price-to-book value of equity is the current total market capitalisation divided by the most recently reported book value of equity. Price-to-earnings (P/E) trailing 12 months is the current share price divided by the per share, last four reported quarters of earnings. P/E last year is calculated using the last reported fiscal year earnings. $\mathrm{P} / \mathrm{E}$ current year is calculated using forecasted current fiscal year earnings. $\mathrm{P} / \mathrm{E}$ next year is calculated using forecasted next fiscal year earnings.

Table 7 displays the estimated price decrease due to a 1 per cent increase in covered healthcare benefits for each firm. The various price-to-earnings methods value the price decrease by multiplying the after-tax per share estimated decrease in reported profits due to the increase in healthcare costs by the corresponding price-to-earnings ratio. For Minnesota, Mining \& Manufacturing the current year $\mathrm{P} / \mathrm{E}$ method estimated share price decrease of $\$ 0.63$ is calculated by the following formula: 
Table 6: Summary financial data

\begin{tabular}{|c|c|c|c|c|c|c|c|c|}
\hline & $\begin{array}{l}\text { Share } \\
\text { price } \\
\text { (\$) }\end{array}$ & $\begin{array}{l}\text { Shares } \\
\text { out. } \\
\text { (bn) }\end{array}$ & $\begin{array}{l}\text { Mkt. } \\
\text { cap. } \\
\text { (\$bn) }\end{array}$ & $\begin{array}{l}\text { Price } \\
\text {-to- } \\
\text { book }\end{array}$ & $\begin{array}{l}\text { P/E } \\
\text { trail. } \\
12 \text { mo. }\end{array}$ & $\begin{array}{l}P / E \\
\text { last } \\
\text { year }\end{array}$ & $\begin{array}{l}\text { P/E } \\
\text { curr. } \\
\text { year }\end{array}$ & $\begin{array}{l}P / E \\
\text { next } \\
\text { year }\end{array}$ \\
\hline Alcoa, Inc. & 37.85 & 0.863 & 32.7 & 2.97 & 22.34 & 20.80 & 19.61 & 13.86 \\
\hline American Express Co. & 41.42 & 1.320 & 54.7 & 4.59 & 26.36 & 20.11 & 27.99 & 17.85 \\
\hline AT\&T Corp. & 20.72 & 3.750 & 77.7 & 0.76 & n.a. ${ }^{a}$ & 12.12 & 109.05 & 57.56 \\
\hline Boeing Co. & 58.82 & 0.853 & 50.2 & 4.37 & 15.91 & 20.35 & 15.32 & 13.13 \\
\hline Caterpillar Inc. & 54.60 & 0.343 & 18.7 & 3.31 & 20.73 & 18.14 & 20.22 & $15.7 \varepsilon$ \\
\hline Citigroup Inc. & 51.05 & 5.030 & 256.8 & 3.84 & 19.32 & 18.36 & 16.96 & 14.75 \\
\hline Coca-Cola Co. & 43.91 & 2.490 & 109.3 & 10.92 & 33.09 & 30.08 & 27.79 & 24.35 \\
\hline E.I. DuPont de Nemours & 42.67 & 1.040 & 44.4 & 3.38 & 41.39 & 15.63 & 31.61 & 20.03 \\
\hline Eastman Kodak Co. & 43.49 & 0.290 & 12.6 & 3.79 & 16.39 & 9.29 & 11.75 & 10.02 \\
\hline Exxon Mobil Corp. & 41.73 & 6.900 & 287.9 & 4.00 & 15.84 & 17.32 & 16.96 & $18.8 \varepsilon$ \\
\hline General Electric Co. & 42.20 & 9.930 & 419.0 & 8.02 & 30.98 & 32.97 & 28.71 & 24.68 \\
\hline General Motors Corp. & 63.46 & 0.549 & 34.8 & 1.19 & 25.48 & 7.53 & 15.59 & $12.6 \mathrm{~s}$ \\
\hline Hewlett-Packard Co. & 25.91 & 1.940 & 50.3 & 3.56 & 22.83 & 14.39 & 35.01 & 24.91 \\
\hline Home Depot, Inc. & 49.78 & 2.330 & 116.0 & 7.41 & 45.34 & 44.85 & 39.82 & $33.1 \mathrm{~s}$ \\
\hline Honeywell International & 36.85 & 0.809 & 29.8 & 3.11 & 47.73 & 12.98 & 16.75 & 14.23 \\
\hline Intel Corporation & 32.11 & 6.720 & 215.8 & 5.88 & 41.59 & 19.46 & 61.75 & 45.23 \\
\hline IBM & 108.80 & 1.740 & 189.3 & 8.91 & 23.21 & 24.45 & 23.76 & 20.84 \\
\hline International Paper Co. & 40.79 & 0.483 & 19.7 & 1.67 & n.a. ${ }^{a}$ & 18.88 & 99.49 & 20.71 \\
\hline J.P. Morgan Chase \& Co. & 43.50 & 1.990 & 86.6 & 2.06 & n.a. ${ }^{a}$ & 14.22 & 17.54 & 12.39 \\
\hline Johnson \& Johnson & 53.19 & 3.030 & 161.2 & 7.41 & 30.71 & 31.11 & 28.29 & $24.4 C$ \\
\hline McDonald's Corp. & 29.15 & 1.290 & 37.6 & 4.22 & 21.26 & 19.83 & 20.97 & 18.81 \\
\hline Merck \& Co., Inc. & 67.79 & 2.290 & 155.2 & 10.48 & 22.46 & 23.38 & 21.59 & 19.76 \\
\hline Microsoft Corp. & 67.45 & 5.380 & 362.9 & 7.67 & 48.56 & 37.27 & 34.77 & 30.80 \\
\hline Minnesota Mining \& Mfg. & 111.29 & 0.394 & 43.9 & 7.17 & 28.66 & 23.78 & 24.35 & 21.24 \\
\hline Phillip Morris Cos. & 45.17 & 2.200 & 99.4 & 5.07 & 12.01 & 12.21 & 11.15 & 9.86 \\
\hline Proctor \& Gamble Co. & 71.46 & 1.300 & 92.9 & 8.22 & 26.91 & 24.22 & 22.98 & 21.65 \\
\hline SBC Comm. Inc. & 44.22 & 3.370 & 149.0 & 4.91 & 18.36 & 19.74 & 18.66 & 17.21 \\
\hline United Technologies & 72.28 & 0.471 & 34.0 & 4.35 & 18.83 & 20.30 & 17.63 & 15.35 \\
\hline Wal-Mart Stores, Inc. & 55.99 & 4.470 & 250.3 & 7.83 & 39.54 & 36.36 & 31.81 & \\
\hline Walt Disney Co. & 26.50 & 2.090 & 55.4 & 2.38 & 131.19 & 33.54 & 29.78 & $29.7 \varepsilon$ \\
\hline Note: DJIA & $10,546.20$ & & & & & & & \\
\hline Sum & $3,548.0$ & & & & & & & \\
\hline Average & 51.12 & 31.37 & 21.73 & 30.20 & 21.86 & & & \\
\hline
\end{tabular}

${ }^{a}$ Negative earnings, therefore no price-to-earnings ratio.

Summary data is as of $08 / 02 / 2001$. Shares outstanding is as of latest reported quarter. Market capitalisation is current share price times shares outstanding. Price-to-book is current market capitalisation divided by most recently reported book value of equity. P/E trailing 12 months is current price divided by last four reported quarters of earnings. P/E last year is calculated using the last reported fiscal year earnings. P/E current year is calculated using forecasted current fiscal year earnings. P/E next year is calculated using forecasted next fiscal year earnings.

Note: Forecasted earnings were collected from The Motley Fool whose data source is I/B/E/S.

$$
\begin{aligned}
\text { price decrease }= & {[(\text { dnpbc })} \\
& \times(1-\text { tax rate }) / \text { shares }] \\
& \times P E
\end{aligned}
$$

where:

price decrease $=$ the share price decrease

dnpbc

tax rate
shares
PE

PE

$$
\begin{aligned}
= & \text { the firm's } 2000 \\
& \text { marginal tax rate }) \\
= & \text { shares outstanding)] } \\
= & \text { the firm's current year } \\
& \mathrm{P} / \mathrm{E} \text { ratio }
\end{aligned}
$$

And applying the formula results in:

$$
\begin{aligned}
\$ 0.63= & {[(\$ 16.00 \mathrm{~m})} \\
& \times(1-.365) /(394.0 \mathrm{~m} \\
& \text { shares })] \times 24.35
\end{aligned}
$$

To calculate the effect of a 1 per cent 
Table 7: Estimated share price and DJIA point decreases due to a 1.0\% increase in covered healthcare benefits using various price-to-earnings valuation methods

\begin{tabular}{|c|c|c|c|c|c|c|c|}
\hline & \multicolumn{5}{|c|}{$\begin{array}{l}\text { Estimated share price decreases } \\
\text { due to } 1 \% \text { increase in covered } \\
\text { healthcare benefits }\end{array}$} & \multicolumn{2}{|c|}{$\begin{array}{l}\text { Current year } \\
\text { P/E method }\end{array}$} \\
\hline & $\begin{array}{l}\text { After-tax } \\
\text { EPS } \\
\text { decrease } \\
(\$ 0.000)\end{array}$ & $\begin{array}{l}\text { Trail. } \\
12 \text { mo. } \\
\text { P/E } \\
\text { method } \\
(\$ 0.00)\end{array}$ & $\begin{array}{l}\text { Last } \\
\text { year } \\
\text { P/E } \\
\text { method } \\
\text { (\$0.00) }\end{array}$ & $\begin{array}{l}\text { Curr. } \\
\text { year } \\
\text { P/E } \\
\text { method } \\
\text { (\$0.00) }\end{array}$ & $\begin{array}{l}\text { Next } \\
\text { year } \\
\text { P/E } \\
\text { method } \\
\text { (\$0.00) }\end{array}$ & $\begin{array}{l}\text { Per cent } \\
\text { price } \\
\text { decrease } \\
\text { (per cent) }\end{array}$ & $\begin{array}{l}\text { Market } \\
\text { cap. } \\
\text { decrease } \\
(\$ \mathrm{~m})\end{array}$ \\
\hline Alcoa, Inc. & 0.009 & 0.21 & 0.19 & 0.18 & 0.13 & 0.48 & 56.2 \\
\hline American Express Co. & 0.002 & 0.04 & 0.03 & 0.05 & 0.03 & 0.12 & 63.0 \\
\hline AT\&T Corp. & 0.001 & n.a & 0.02 & 0.15 & 0.08 & 0.74 & 572.0 \\
\hline Boeing Co. & 0.053 & 0.85 & 1.08 & 0.82 & 0.70 & 1.39 & 695.6 \\
\hline Caterpillar Inc. & 0.082 & 1.70 & 1.48 & 1.65 & 1.29 & 3.03 & 567.8 \\
\hline Citigroup Inc. & 0.001 & 0.01 & 0.01 & 0.01 & 0.01 & 0.02 & 43.6 \\
\hline Coca-Cola Co. & 0.002 & 0.07 & 0.06 & 0.06 & 0.05 & 0.13 & 142.4 \\
\hline E.I. DuPont de Nemours & 0.029 & 1.20 & 0.45 & 0.91 & 0.58 & 2.14 & 950.4 \\
\hline Eastman Kodak Co. & 0.014 & 0.22 & 0.13 & 0.16 & 0.14 & 0.37 & 46.5 \\
\hline Exxon Mobil Corp. & 0.002 & 0.33 & 0.03 & 0.03 & 0.03 & 0.07 & 212.4 \\
\hline General Electric Co. & 0.000 & 0.00 & 0.00 & 0.00 & 0.00 & 0.00 & 0.0 \\
\hline General Motors Corp. & 0.534 & 13.59 & 4.02 & 8.32 & 6.77 & 13.11 & $4,563.5$ \\
\hline Hewlett-Packard Co. & 0.004 & 0.09 & 0.06 & 0.14 & 0.10 & 0.54 & 269.6 \\
\hline Home Depot, Inc. & 0.000 & 0.00 & 0.00 & 0.00 & 0.00 & 0.00 & 0.0 \\
\hline Honeywell International & 0.009 & 0.45 & 0.12 & 0.16 & 0.13 & 0.43 & 127.5 \\
\hline Intel Corporation & 0.000 & 0.00 & 0.00 & 0.00 & 0.00 & 0.00 & 0.0 \\
\hline IBM & 0.003 & 0.07 & 0.08 & 0.08 & 0.07 & 0.07 & 133.3 \\
\hline International Paper Co. & 0.000 & n.a. & 0.00 & 0.00 & 0.00 & 0.00 & 0.0 \\
\hline J.P. Morgan Chase \& Co. & 0.001 & n.a. & 0.01 & 0.01 & 0.01 & 0.02 & 19.5 \\
\hline Johnson \& Johnson & 0.003 & 0.08 & 0.08 & 0.07 & 0.06 & 0.14 & 225.4 \\
\hline McDonald's Corp. & 0.000 & 0.00 & 0.00 & 0.00 & 0.00 & 0.00 & 0.0 \\
\hline Merck \& Co., Inc. & 0.06 & 0.13 & 0.13 & 0.12 & 0.11 & 0.18 & 280.3 \\
\hline Microsoft Corp. & 0.000 & 0.00 & 0.00 & 0.00 & 0.00 & 0.00 & 0.0 \\
\hline Minn. Mining \& Mfg. & 0.026 & 0.74 & 0.61 & 0.63 & 0.55 & 0.56 & 257.4 \\
\hline Phillip Morris Cos. & 0.008 & 0.10 & 0.10 & 0.09 & 0.08 & 0.21 & 204.0 \\
\hline Proctor \& Gamble Co. & 0.011 & 0.30 & 0.27 & 0.26 & 0.25 & 0.36 & 338.1 \\
\hline SBC Comm. Inc. & 0.035 & 0.65 & 0.70 & 0.66 & 0.61 & 1.49 & $2,214.5$ \\
\hline United Technologies & 0.011 & 0.21 & 2.22 & 0.19 & 0.17 & 0.27 & 91.0 \\
\hline Wal-Mart Stores, Inc. & 0.000 & 0.00 & 0.00 & 0.00 & 0.00 & 0.00 & 0.0 \\
\hline Walt Disney Co. & 0.002 & 0.27 & 0.06 & 0.07 & 0.06 & 0.26 & 146.6 \\
\hline Average & 0.87 & 410.4 & & & & & \\
\hline Sum & 21.01 & 9.95 & 14.82 & 12.0012 & 10.9 & & \\
\hline Decrease in DJIA & 145.36 & 68.88 & 102.55 & 83.04 & 0.97 & & \\
\hline
\end{tabular}

This table estimates the share price decrease due to a $1 \%$ increase in covered healthcare benefits for each firm. The after-tax EPS decrease is reported increase in net periodic benefit cost due to a $1 \%$ increase in covered healthcare benefits, times one minus the firms effective tax rate for fiscal year 2000 , divided by shares outstanding. The various price-to-earnings methods estimate the price decrease by multiplying the after-tax earnings per share decrease by the corresponding P/E ratio. The per cent price decrease is the estimated per share price decrease divided by the current share price as of 08/02/2001. Market capitalisation decrease is the per cent price decrease multiplied by the firms market capitalisation. For each method the price decrease for the DJIA is calculated by summing the price decreases for all 30 firms and dividing that sum by the current DJIA divisor, currently 0.14452124 .

increase in the healthcare trend rate on the price weighted DJIA, you take the price weighted average of the price decreases of the 30 Dow firms.

Specifically, you sum the price changes and divide by the DJIA divisor, presently 0.14452124 . For the current $\mathrm{P} / \mathrm{E}$ method, the sum of the 30 price changes, 14.82 , divided by the divisor, 0.14452124 , yields an estimated decrease in the DJIA of 102.55 points. Or approximately 0.97 per cent from the presently level of $10,546.202 .{ }^{9}$ The estimated decrease in the DJIA differs 
from method to method, depending on the $\mathrm{P} / \mathrm{E}$ multiple use in the calculation. The current $\mathrm{P} / \mathrm{E}$ method yields an average market capitalisation decrease of $\$ 410.4 \mathrm{~m}$ for each firm. The total market capitalisation loss is estimated to be $\$ 12,310.9 \mathrm{~m}$.

The impact of the Patients' Bill of Rights on EPS varies greatly for the firms in the DJIA. The impact is greatest for the 'old economy' manufacturing firms: General Motors, Caterpillar, Dupont, SBC, and Boeing. A 1 per cent increase in assumed healthcare inflation costs GM \$2.172bn. The cost to the other four firms is as follows: SBC $\$ 1.011 \mathrm{bn}$, Boeing $\$ 553 \mathrm{~m}$, Dupont $\$ 309 \mathrm{~m}$, and Caterpillar $\$ 259 \mathrm{~m}$.

Translated into EPS a 1 per cent increase in healthcare costs reduces per share earnings for GM by $53.4 \phi$ per share, Caterpillar 8.2ф, Boeing 5.3ф, SBC 3.5ф, and Dupont $2.9 \phi$. Using the current year price-to-earnings multiple, stock prices for this groups of firms would decrease from between $66 \not \varnothing$ per share (SBC) to $\$ 8.32(\mathrm{GM})$. If costs increase by 4 per cent as estimated by the $\mathrm{CBO}$ the price impacts would be significant for all five companies: SBC $\$ 2.64$, Boeing $\$ 3.28$, Dupont $\$ 3.64$, Caterpillar $\$ 6.60$, and GM $\$ 33.28$. The actual impact may be less since the costs phase in over five years and the $\mathrm{CBO}$ expects firms to mitigate 60 per cent of the cost increases.

At the other end of the spectrum, are a group of 'new economy' firms in the technology, retail and service (fast food) industries. This group consists of Home Depot, Intel, Microsoft, Wal-Mart, and McDonald's. There is no impact on the reported earnings for these firms since they do not offer post-retirement healthcare benefits to their employees. Or they offer a defined contribution benefit where company costs are limited to a fixed dollar amount or a percent of wages and salaries. These five firms also do not provide employees defined benefit pension plans, instead offering defined contribution benefits plans consisting of $401(\mathrm{~K})$ plans, profit sharing plans, and stock options. These five firms offer a glimpse of the future of pension and healthcare benefits. The increased reliance of defined contribution plans that provide a degree of cost certainly and cost containment to employers.

The price-to-book value of equity valuation method concerns the post-retirement benefit obligation figure. The benefit obligation figure is a liability on the balance sheet. Therefore, any increase in this figure would decrease the book value of equity of the firm. Table 8 displays the valuation implication of the reported effect of a 1 per cent increase in healthcare trend rates on the price per share and market value of equity for each firm. This method multiplies the estimated increase in per share benefit obligation by the current period price-to-book value of equity ratio.

For Minnesota, Mining \& Manufacturing, the price-to-book value valuation calculation would be the following:

$$
\begin{aligned}
\text { price decrease } \quad= & {[(d b o) /(\text { shares })] } \\
& \times \text { PtoB }
\end{aligned}
$$

where:

$$
\begin{array}{ll}
\text { price decrease }= & \text { share price } \\
& \text { decrease } \\
\text { dbo } & \text { reported effect of } \\
& 1 \text { per cent increase } \\
& \text { in healthcare trend } \\
& \text { rates on benefit } \\
& \text { obligation } \\
= & \text { shares outstanding } \\
= & \text { the firm's current } \\
& \text { period price-to- } \\
& \text { book value of } \\
& \text { equity ratio } \\
\text { shares } &
\end{array}
$$


Table 8: Estimated share price and DJIA point decrease due to a $1.0 \%$ increase in covered healthcare benefits using price-to-book value of equity valuation method

\begin{tabular}{|c|c|c|c|c|}
\hline & $\begin{array}{l}\text { Per share } \\
\text { increase } \\
\text { in benefit } \\
\text { obligation } \\
(\$ 0.000)\end{array}$ & $\begin{array}{l}\text { Share } \\
\text { price } \\
\text { decrease } \\
(\$ 0.00)\end{array}$ & $\begin{array}{l}\text { Per cent } \\
\text { price } \\
\text { decrease } \\
\text { (per cent) }\end{array}$ & $\begin{array}{l}\text { Market } \\
\text { cap. } \\
\text { decrease } \\
(\$ \mathrm{~m})\end{array}$ \\
\hline Alcoa, Inc. & 0.191 & 0.57 & 1.50 & 490.1 \\
\hline American Express Co. & 0.014 & 0.06 & 0.16 & 85.3 \\
\hline AT\&T Corp. & 0.033 & 0.03 & 0.12 & 95.0 \\
\hline Boeing Co. & 0.707 & 3.09 & 5.25 & $2,635.1$ \\
\hline Caterpillar Inc. & 0.815 & 2.70 & 4.94 & 926.8 \\
\hline Citigroup Inc. & 0.008 & 0.03 & 0.06 & 145.9 \\
\hline Coca-Cola Co. & 0.022 & 0.24 & 0.55 & 600.6 \\
\hline E.I. DuPont de Nemours & 0.426 & 1.44 & 3.37 & $1,497.3$ \\
\hline Eastman Kodak Co. & 0.286 & 1.08 & 2.49 & 314.6 \\
\hline Exxon Mobil Corp. & 0.038 & 0.15 & 0.36 & $1,036.8$ \\
\hline General Electric Co. & 0.000 & 0.00 & 0.00 & 0.0 \\
\hline General Motors Corp. & 9.479 & 11.28 & 17.77 & $6,188.0$ \\
\hline Hewlett-Packard Co. & 0.003 & 0.12 & 0.45 & 227.8 \\
\hline Home Depot, Inc. & 0.000 & 0.00 & 0.00 & 0.0 \\
\hline Honeywell International & 0.161 & 0.50 & 1.36 & 404.3 \\
\hline Intel Corporation & 0.000 & 0.00 & 0.00 & 0.0 \\
\hline IBM & 0.030 & 0.27 & 0.24 & 463.3 \\
\hline International Paper Co. & 0.130 & 0.22 & 0.53 & 105.2 \\
\hline J.P. Morgan Chase \& Co. & 0.024 & 0.05 & 0.12 & 100.2 \\
\hline Johnson \& Johnson & 0.029 & 0.22 & 0.41 & 659.5 \\
\hline McDonald's Corp. & 0.000 & 0.00 & 0.00 & 0.0 \\
\hline Merck \& Co., Inc. & 0.063 & 0.67 & 0.98 & $1,523.8$ \\
\hline Microsoft Corp. & 0.000 & 0.00 & 0.00 & 0.0 \\
\hline Minnesota Mining \& Mfg. & 0.302 & 2.17 & 1.95 & 853.2 \\
\hline Phillip Morris Cos. & 0.142 & 0.72 & 1.59 & $1,583.7$ \\
\hline Proctor \& Gamble Co. & 0.128 & 1.06 & 1.48 & $1,372.7$ \\
\hline SBC Comm. Inc. & 0.593 & 2.91 & 6.59 & 9.815 .1 \\
\hline United Technologies & 0.150 & 0.65 & 0.90 & 306.7 \\
\hline Wal-Mart Stores, Inc. & 0.000 & 0.00 & 0.00 & 0.0 \\
\hline Walt Disney Co. & 0.042 & 0.10 & 0.37 & 207.1 \\
\hline Average & 1.79 & $31,638.2$ & & \\
\hline \multicolumn{5}{|l|}{ Sum } \\
\hline Decrease in DJIA & 209.71 & 1.99 & & \\
\hline
\end{tabular}

This table estimates the share price decrease due to a $1 \%$ increase in covered healthcare benefits for each firm. The per share increase in benefit obligation is the stated increase in benefit obligation for a $1 \%$ increase in the cost of covered healthcare benefits divided by shares outstanding. The share price decrease multiplies the estimated increase in per share benefit obligation by the current period price-to-book value of equity ratio. The per cent price decrease is the estimated share price decrease divided by the current share price as of $08 / 02 / 2001$. The market capitalisation decrease is the percent price decrease multiplied by the firms market capitalisation. The price decrease for the DJIA is calculated by summing the price decreases for all 30 firms, for each method, and dividing that sum by the current DJIA divisor, currently 0.14452124 .

And applying the formula results in:

$$
\begin{aligned}
= & {[(\$ 119.00 \mathrm{M}) /} \\
& 394.1 \mathrm{~m} \text { shares })] \\
& \times 7.17
\end{aligned}
$$

The estimated point loss in the DJIA for a 1 per cent increase in healthcare trend rates is 209.71 using the current price-to-book value of equity method. The estimated market capitalisation loss for a 1 per cent increase in healthcare trend rates is $\$ 31,638.2 \mathrm{~m}$ for the Dow. This number is drastically different from the current year $\mathrm{P} / \mathrm{E}$ method for several reasons. The main reason being that the benefit obligation is the estimated, present value, of all post-retirement benefits costs, vs. the net periodic benefit cost being just the one year effect of those costs. 
Table 9 shows the estimated share price decreases due to 1.6 per cent, 2.0 per cent, 3.0 per cent, 4.0 per cent and 5.0 per cent increases in covered healthcare benefits for each firm for both the current $\mathrm{P} / \mathrm{E}$ method and the current price-to-book value method. The 1 per cent share price decreases from Tables 7 and 8 are scaled by 1.6, 2, 3, 4, and 5 times to estimate the various per share decreases.

The 1.6 per cent columns represent the estimates based on the CBO's estimate of 4.0 per cent less the 'offsets' of 60 per cent of the 4.0 per cent estimate. The CBO states that 60 per cent of the increase will be offset by changes in profits and by purchasers switching to less expensive plans, cutting back on fringe benefits, or dropping coverage. For the current $\mathrm{P} / \mathrm{E}$ valuation method, the estimated effect on the DJIA of a 4.0 per cent increase in healthcare benefit costs, offset by 60 per cent, is a decrease of 164.08 points. However, the authors feel that including the 'changes in profits' in the offset calculation to be somewhat tenuous. Therefore, the authors estimate the effects of a 2.0 per cent, 3.0 per cent, 4.0 per cent, and 5.0 per cent increase. For the current price-to-book value method, the estimated effect on the DJIA of a 4.0 per cent increase in healthcare benefit costs, offset by 60 per cent, is a decrease of 335.54 points.

\section{Conclusion}

Enactment of a Patients' Bill of Rights will increase the cost of providing healthcare to employees by 4 per cent according to the CBO. If this cost is not passed on to employees, the cost increases will reduce profits and EPS, which will impact stock prices and market capitalisation. The impact of a 4 per cent increase in healthcare costs on the earnings of the Dow 30 stocks would be significant. Depending on the valuation method chosen, a reduction in the level of the DJIA of between 410.20 and 838.86, and a corresponding loss of market capitalisation between $\$ 49.2 \mathrm{bn}$ and $\$ 126.6$ bn would occur.

The CBO estimates that 60 per cent of the cost increases to firms will be mitigated through a combination of increased future earnings and passing cost increases on to employees. The argument that future earnings increases will absorb the increased cost of healthcare is spurious at best. Increased healthcare costs will hold down the level of future earnings deterring future stock price growth even if there is no impact on the $\mathrm{P} / \mathrm{E}$ multiple. The multiple is a function of investors expectations of future growth in earnings. Using the constant growth Dividend Discount Model, P/E can be expressed as follows:

$$
P E \quad=\text { payout } /(k-g)
$$

where:

$$
\begin{aligned}
\text { payout }= & \text { the dividend payout } \\
& \text { percentage } \\
\mathrm{k} \quad & \text { investors required rate of } \\
& \text { return } \\
\mathrm{g} \quad & \text { the expected future rate of } \\
& \text { growth in dividends and } \\
& \text { earnings }
\end{aligned}
$$

The higher the growth rate expected by investors the lower the capitalisation rate $(\mathrm{k}-\mathrm{g})$ and the higher the $\mathrm{P} / \mathrm{E}$ multiple. If cost increases for healthcare depress future earnings expectation the firms multiple may be adjusted downward by investors further negatively impacting stock price.

The impact of the bill on corporate profits may be tempered by the fact that FASB has recently changed the way corporations account for goodwill on 


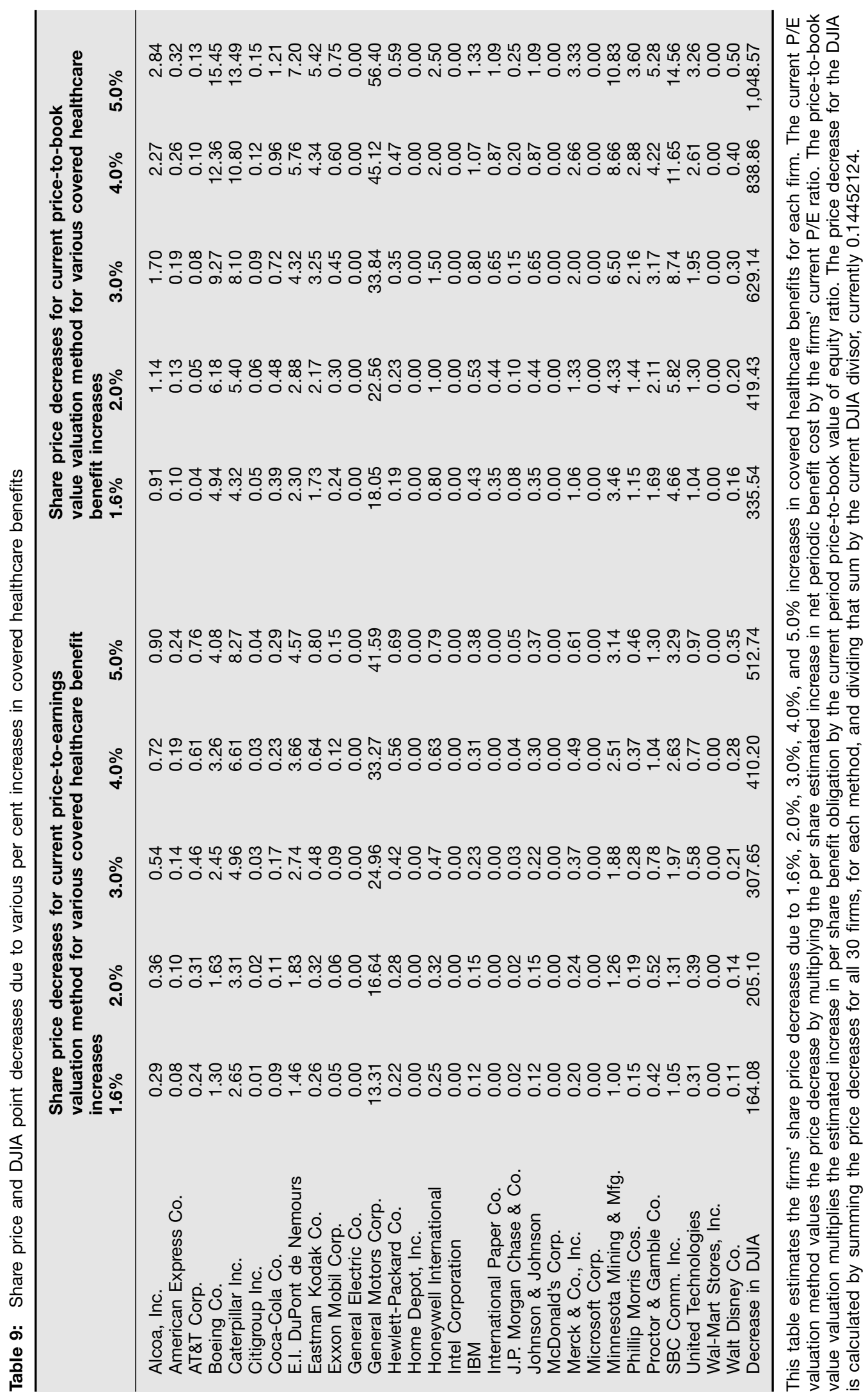


their financial statements. Historically when a firm acquired another firm and paid more than the adjusted book value the excess (depending on the accounting technique chosen) would be considered goodwill. Goodwill is entered on the firm's balance sheet and amortised over a period not to exceed 40 years. The annual amount amortised appeared on the income statement as an expense reducing profits. The FAS would no longer require firms to show this expense on their income statement boosting reported profits. Depending on the firm this impact may offset or even exceed the negative impact of increases in healthcare costs on the income statement.

In an efficient market investors should focus on cash flows rather than EPS. The impact of the two events is not offsetting. The increase on healthcare costs will have negative cash flow consequences, the goodwill adjustment will not generate positive cash flow since goodwill is a non cash expense.

Passing on cost increases to employees is the more likely corporate response. As mentioned earlier, the average costs of family coverage is $\$ 7,020$ with employees paying 22 per cent or $\$ 1,544$ and employers paying 78 per cent or $\$ 5,476$ dollars. The Towers Perrin 2001 Health Care Cost Survey showed that 40 per cent of employers passed on a greater that proportional share of cost increases to employees in 2000. The Patients' Bill of Rights will accelerate the trend, toward a defined contribution system of providing healthcare benefits. In this system employers contribute a fixed number of dollars or a percentage of earnings into an account, which the employee uses to purchase their own healthcare coverage. The employee can add their own money into the account to purchase more extensive coverage if they desire. Employers provide a list of approved vendors and programmes to choose from, in addition to employee information and counselling sessions. The choice of coverage is left to the employee under this type of system. The employer gets cost certainty and protects their income statement from unexpected increases in healthcare costs. The first court case in which a large employer is held liable for denial of care in a plan they self-insure will transform a gradual movement toward defined contribution healthcare plans into a stampede.

\section{References}

1 Transnational Accounting (1995) Vol. 2, IASC-USA, edited by Dieter Ordelheide and KPMG, Macmillan Press Ltd, p. 2724.

2 Williams, J. (2001) '2001 Miller GAAP Guide: Restatement and Analysis of Current FASB Standards', Chapter 35, Harcourt Professional Publishing.

3 Schultz, E. (2000) 'Companies Transform Retiree Medical Plans into Sources Profit', The Wall Street Journal, 25th October, A1.

4 Schultz, E. and McGough, R. (2000) 'Using a Trust Fund to help pay retiree benefits in the future can help the bottom line now', The Wall Street Journal, 25th October, C1.

5 KPMG Peat Marwick (2001) 'Source Book of Health Insurance Data 1999-2000 Health Insurance Association of America', KPMG Peat Marwick, survey of employer-sponsored health benefits, from 'Trends in Health Care Spending in the Private Sector' section.

6 Towers Perrin (2000) Health Care Cost Survey.

7 Towers Perrin (2001) Health Care Cost Survey.

8 Forecasted earnings were collected from The Motley Fool website whose data source is $\mathrm{I} / \mathrm{B} / \mathrm{E} / \mathrm{S}$.

9 As of $08 / 02 / 01$. 